\title{
How artists working in academia view artistic practice as research: implications for tertiary music education
}

Artistic research output struggles for recognition as 'legitimate' research within the highly competitive and often traditional university sector. Often recognition requires the underpinning processes and thinking to be documented in a traditional written format. This article discusses the views of eight arts practitioners working in academia by asking whether or not they view their arts practice as research; and if they do, how it is so. The findings illuminate ways in which artistic practice is understood as research and reveal how the process of analytical and reflective writing impacts artist academics, their artistic and academic identities and their environment. The findings suggest a frame within which to advocate the equivalence of artistic research with traditional scholarly research. They also suggest a rationale for arguing against this, focusing instead (or perhaps as well) on a wider understanding of what constitutes knowledge. This has implications for academics, for students and for universities in recognising the research inherent within arts practice itself, and in recognising the value of practice-led writing in understanding and communicating new knowledge, new methods, and new definitions of research.

\section{Keywords}

artist academics; artistic research; arts practice; research

\section{How artists working in academic view artistic practice as research: implications for tertiary music education}

\section{Introduction}

Artistic research output struggles for recognition as 'legitimate' research within the highly competitive and often traditional university sector. Many arts practitioners work as academics within higher education, where they continue their artistic practice and share their skills and knowledge of arts practice with undergraduate and postgraduate students. Often, however, recognition of their artistic research requires the underpinning processes and thinking to be documented in a traditional written format. Artistic practice as research - as a site of knowledge ${ }^{1}$ - is rarely recognised as research in its own right. As arts faculties vie for limited funding with an increasingly

\footnotetext{
${ }^{1}$ This term draws on the Frascati definition of Research and Development as 'creative work undertaken on a systematic basis in order to increase the stock of knowledge, including knowledge of man, culture and society, and the use of this stock of knowledge to devise new applications' (p. 30, Frascati Manual, 2002).
} 
complex environment, artists working as academics have to rethink the relationship and interactions between their academic and artistic identities.

This article discusses the responses of eight arts practitioners working in academia as to whether or not they view their arts practice as research; and if they do, how it is so. The data collection occurred within the twelve months prior to the introduction of the Australian research framework Excellence for Research in Australia (ERA) ${ }^{2}$, which recognizes creative practice as research. The study illuminates ways in which artistic practice is understood as research, and discusses the implications for tertiary teaching in the musical, performing and visual arts,.

Although there is a body of literature on arts practice, much of this research comes from researchers who are not arts practitioners; however, writing by practitioners is accumulating. The literature on arts practice as research is in itself a paradox: if artists in academia write about their arts practice they have immediately identified two research modes for their practice. If they don't write about their arts practice but they are prepared to be interviewed, thereby allowing someone else to write about it, they are adopting a passive approach to discussion about their practice, an approach often criticised by arts practitioners themselves. In this paper we discuss practitioner and non-practitioner-derived literature as it relates to the findings.

\section{Methodology}

\footnotetext{
${ }^{2}$ http://www.arc.gov.au/era/default.htm
} 
This paper discusses the views of arts practitioners working in Australian academic institutions and responds to three research questions:

a) Do artists in academic view their arts practice as research/a site of knowledge?

b) If they do view their arts practice as research, how it is so?

c) What is the impact of thinking analytically and reflectively about one's arts practice?

Eight arts practitioner participants were identified for interview from within professional networks in Australian universities. Four were musicians, each engaging with a different aspect of music practice (composer, song writer, electroacoustic composer/performer and keyboard player). Two were engaged in theatre (actor, director), one in dance and one as a ceramicist. This purposeful sampling was employed to locate participants who were likely to give a wealth of information with respect to the study (Patton 1990). Before interviewing commenced, participants were asked to make two marks on a continuum: 1) were they perceived themselves as artists and as academics; and 2) where they situated their research (Table 1).

\section{Table 1 Continuum}

The Artist as Academic

Name of participant: $\quad$ Name of interviewer:

Date:

1. Mark (with a black pen) where you perceive yourself in the university environment as artist and as academic.

2. Mark (with a red pen) to situate your research on the continuum

Artist-------------------------------------------------I-----------------------------------------------Academic 
Each interview began by building a short participant profile seeking information on qualifications, academic position, years spent in academia, and a description of his/her arts practice. Participants were asked two further questions, which they had been given prior to the interview: i) do you view your arts practice as a site of knowledge (that is, as research)? ii) If so, how is it so? Interviews were recorded and transcribed.

Analysis

Analysis of the continuum responses divided the line into three sections for discussion - artist (the left third), academic (the right third), and the middle third. Profile data was placed into a table (Table 3) and responses to the first question were analysed in relation to the coding of 'yes', 'no', 'somewhere in-between' or a combination of the two responses. However as participants explained their thinking in relation to this question, and responded to the final question, new ideas emerged. For this, analysis initially adopted Glaser's 'constant comparative method' whereby codings were compared 'over and over again with codings and classifications that have already been made’ (Flick 2002, p. 231). At the same time, because we were seeking new responses to the topic, aspects of grounded theory approach to analysis were adopted to identify and describe the predominant thinking that appears to shape artistacademics' work. This approach follows that taken by Burnard, Dillon, Rusinek and Sæther (2008) in their study of teachers' practice. The approach also enabled us to develop 'analytical interpretations of ... data to focus further data collection' (Charmaz 2000, 509), thus helping to identify future research areas. 


\section{Findings}

In relation to the continuum, all participants placed their research within the artist third or in the middle (see Table 2). For their roles as artist and academic, three placed themselves in the artist third, three in the academic third, and two placed themselves in the middle. Clare the composer said she engaged with both parts of the continuum spectrum depending on the day and task, thus choosing to situate herself in the middle of the continuum. Clare's description of her artist/academic identity typifies the action of 'switching on and off' contrasting identities according to role.

\section{Table 2: Continuum placement}

\begin{tabular}{|l|l|}
\hline \multicolumn{2}{|l|}{ Question 1: Mark where you perceive yourself in the university environment as artist and as academic } \\
\hline Artist third & 3 \\
\hline Middle third & 2 \\
\hline Academic third & 3 \\
\hline Question 2: Mark where you situate your research on the continuum & \\
\hline Artist third & 5 \\
\hline Middle third & 3 \\
\hline Academic third & 0 \\
\hline
\end{tabular}

The profile summary noted that all arts practitioner participants had an active professional practice and all were employed as academics in Australian universities. Their arts disciplines, lengths of time in academia, and post-graduate qualification levels are given in Table 3.

Table 3: Participant profiles

\begin{tabular}{|l|l|l|l|}
\hline $\begin{array}{l}\text { Study } \\
\text { name }\end{array}$ & $\begin{array}{l}\text { Years as } \\
\text { academic }\end{array}$ & Arts discipline & Post-graduate qualification \\
\hline Ava & 10 & Actor & Completing a PhD \\
\hline Brian & $5-6$ & $\begin{array}{l}\text { Electro-acoustic composer and } \\
\text { performer }\end{array}$ & PhD \\
\hline Clare & 40 & Composer & PhD \\
\hline Damon & 4 & Songwriter, popular musician & Currently enrolled MA \\
\hline
\end{tabular}




\begin{tabular}{|l|l|l|l|}
\hline Ellen & 15 & Dancer & PhD (literature) \\
\hline Fiona & 10 & Drama teacher, theatre director & Currently enrolled PhD \\
\hline Gina & 14 & Ceramicist & PhD \\
\hline Henry & 12 & Keyboard performer & Currently enrolled PhD \\
\hline
\end{tabular}

\section{Arts practice as a site of knowledge and/or as research}

All participants considered their arts practice to be a site of knowledge. For two participants, Brian and Gina, the artistic outcome or artistic object does not stand alone as research. It is the development process that is research and, therefore, their arts practice outcome is a site of knowledge but not research. Composers Reiner and Fox (2003) agree to this response in relation to experimental music, finding that 'the object of art or the composition outcome is not the primary focus of the investigation or experiment', rather the focus is on the systematic process (p. 6). Brian spoke of the discoveries made during the process and, being an academic, the need to:

...contribute to the body of knowledge and be part of the discourse. If you don't feel the need to do that then you can just do your stuff in your studio and go and do your performances and so on. ...I see that as just practice and I don't see it as research really until it becomes more explicit and is shared and is open to other people.

Henry, a keyboard performer, said the artistic outcome is more important than the codifying of the process, although both are research. While his university's emphasises the exegetical writing rather than the artistic outcome itself, he says ‘...you must have the performance, if not have both'.

How arts practice is research 
For four participants the artistic process is research involving aspects of the unexpected, intuitive, mysterious, and serendipitous. Damon felt that his practice is both a site of knowledge and research. He called it 'an intuitive mode of research' which he is not interested in analysing because he has '... a kind of superstition about that, almost'; and Fiona talked of 'there [being] a sense that you are entering a world of mysticism when you are talking about processes of acting'. Singer songwriter Paul Simon agrees with Damon's reference to intuition and reminds us that it is difficult to write about one’s arts practice: ‘The music part of song writing is much more potent and powerful than the lyric part. But it's harder to write about' (Simon, in Flanagan 1986/87, p. xi). Other songwriters describe mystic, unknown processes. For Keith Richards, songs 'arrive at your doorstep and all you do is give them an airing, make it possible for them to exist’ (Richards, interviewed by Flanagan 1986/87, p. xiii), while Bono 'feel[s] like the songs are already written' (Bono, interviewed by Flanagan 1986/87, p. xii). This sense of the unexpected was also heard when Ava and Fiona, both theatre artists, talked of the process as a journey not clearly articulated - 'an unfolding or a revelation rather than a decisive direction'. Both drew attention to the unexpected being part of the process saying that the artistic process is serendipity, associated with speculations, and actors are not sure what is going to happen next.

Four participants spoke of the artistic process as holistic, offering different viewpoints of the human being as a site of knowledge. Damon described his life history as scholarship, that is, '... as a scholar of popular music, and I mean popular in the absolutely widest sense'. This has taken place through playing popular music, collecting recordings and, from 13-14 years of age, song writing. In later years he embarked upon journalistic writing and, more recently, academic writing about 
popular music. A classical music composer working in academia, Bruce Crossman (2005) expressed a similar link between artistic practice and life history. For Crossman the composition process involves the development of a 'personal compositional voice' which, for him, includes a broad personalised range of interests unique to the individual: 'a type of cultural DNA' (no page) that nurtures a composer's inner voice. Through collaboration and discussion with others, Ava (actor) described how '...a lot of knowledge is drawn upon...it is a site of sophisticated knowledge' and Fiona talked of actors being tested '...to [such] a depth that there is a visceral response'. Fiona drew on Gadamer's notion of 'shared horizons', saying: 'we are shifting our bodies into understanding another writer and through that empathic link we are taking an understanding ... and this is the way history is formed'. This thinking also emerged in Wright's (2002) writing about a project in which Western-trained actors were introduced to the training methods and performance styles of Peking Opera by Chinese actors and musicians who spoke very little English. He found that he was bringing the Peking Opera character-types close to his own experience:

I was, I realised, writing my experience as theirs. ... While my experience is not that of an alien culture it includes enough to allow me to try to feel my way into the experience of these others. Yet, while representing others to others, it is remarkable for me to realise that I am finally only talking to and about myself (p. 12).

Clare, a composer, also spoke of the visceral and beyond, drawing on emotion, sensory perception and social intelligence among other aspects and dealing with a whole range of intelligences. An holistic activity, her whole self is engaged in the process, body and mind, and 'the heart is particularly important'. And Brian also 
described '...senses and approaches to interaction, artificial intelligence engines and all sorts of stuff to try to look at how ...to produce complex notions and mapping and inter-relationships that allow me to get a strength of expressivity and a strength of timbral morphology and so on into the sounds that are coming out ... [and] the ability to nuance them'. Interviews with pianist Glenn Gould reveal these different creative and cognitive issues and decisions involved when he performed on the piano. He described the role of the performer as 'someone who should be more concerned with the development of musical and spiritual ideas rather than the physical manifestations connected with music making' (in Angilette 1992, p. 91). For this to occur, Gould first commits a musical score to memory and only later plays it on the piano, and he describes his method in detail. Here the holistic body - visceral, emotional, spiritual, mental and physical - is in play.

Brian and Damon spoke of arts practice as being about itself, organizing sound through consideration of issues such as structure, timbre and content. This reflects the thinking of composers Reiner and Fox (2003), for whom aesthetic knowledge is largely non-verbal by nature, and 'music, and more specifically music composition, promotes abstract thinking because in its purest form, when it is concerned with sound and sound structures, it does not engage in representation' (p. 7). Both Brian and Fiona talked, in different terms, of working through '....arduous skilled regimes' (Fiona), whether they be through sound, voice, or movement.

Three participants said their arts practice communicated beyond its own medium. Clare and Fiona each identified as a '...creative mind which is part of a broader tradition...' (Fiona), with each arts practice '...leap[ing] out beyond boundaries of 
your discipline (true of every creative thinker) and engag[ing] with other areas’ (Clare) including science, philosophy, psychology. Clare and Ava spoke of themselves as storytellers or public intellectuals within their community which is part of an international community of arts practitioners '...thinking through things in the public arena'.

The impact of thinking and writing analytically and reflectively about one's arts practice

Knowledge growth and informed teaching

Because the participants acknowledge artistic practice as a site of knowledge, whether artistic process, outcome or both, understanding this knowledge impacts in different ways. For five of the participants, writing about one's arts practice feeds into that arts practice, improving its growth, and impacting on teaching. It is '...the stuff that excites artists [which] contributes to the evolution of their own thinking as artists' (Ava). Arts practice is heightened 'because it has empowered me [Gina] to analyse it, critique it, reflect on it'; and for Fiona, 'there is no doubt that it has helped me to articulate my practice... [and] had immense impact upon my teaching'. Damon says it is a cycle in which '...broad knowledge equals scholarship which feeds into your research and certainly ...feeds into your teaching as well and probably feeds into your song writing as well'. Ellen, a dancer, talks of 'tacit knowledge that people don't know they have' and of the difficulty of getting dancers to understand that talking about their arts practice feeds into their arts practice: 'you make concepts when you create an artwork'. Observing her students, when required to document their artistic process, Gina noticed that 'students struggle whilst they're in the research process, but 
at the end they all say that it was one of the most important things they had ever done as an artist. To me, that's where the validity is'.

\section{Influence of the university environment}

Three participants in dance and theatre articulated clearly how working in a university environment and the pressure of undertaking written academic enquiry changed their views of writing about their artistic practice. Still completing her $\mathrm{PhD}$, Ava was not sure if she would undertake practice-led writing if she wasn't working in a university. She viewed her thesis as, in some way, an art work, and herself as historian and anthropologist with research throwing up patterns and key issues. This has resonances with Mullen's suggestion that 'the rendering of research texts are "performances", (Mullen, 2003 cited in Dixson, Chapman and Hill, 2005, p. 19). Heading up a research program designed to encourage arts practitioners in a British tertiary conservatoire to engage in systematic enquiry through practice-based research into their own arts practice, George Odam (2001) describes this approach as being 'at the forefront of arts research thinking ... plac[ing] the artist and her/his own practice at the centre of the enquiry and ... usually carried out by the artist' (p. 81). For the artist working in academia, systematic enquiry into his/her arts practice stimulates 'interesting thoughts ... concerning the way our society values, understands, trusts and respects its artists and teachers' (p. 82). These 'interesting thoughts' challenge the notation of established research paradigms and this suggests strong concurrence with some of the problems that face the artist-academic in claiming or re-claiming the research that comprises the practice. 


\section{Time and mindset}

Time to write and to practice, and the different thinking required, were issues for participants. Fiona felt that the pressure to write meant making less time for practice and more for writing, forcing a division between practitioners and scholars but she supported both activities. Both Gina and Ellen spoke of the time and different mindsets required for artistic critique and artistic practice. In Ellen's case, this imposed on her a jump from being a dancer to being an academic while Gina saw practice and theory as not separate roles, but roles requiring dedicated focus and time. In part, this reflects the physical nature of dance practice. Through her own experience and that of her students, Gina, understands that the analysis of artistic process cannot occur at the same time as the arts practice itself. Postgraduate students '...may have one month in the studio and then one month writing, or three months. I've never seen anyone spend the morning in the studio and the afternoon writing'. However, it is through this research process that the validity is drawn.

\section{Ideas of arts practice as research}

Several ideas of arts practice as research were identified by participants and in the literature. Fiona identified four types of research: scientific, theoretical, clinical, and creative research, with creative research not really understood. By creative research she means research about arts practice, what this paper calls artistic research. For her, creative research can be legitimized by adopting methodological labels such as action research, phenomenology or grounded theory, with no single agreed-upon paradigm through which to report. Dancer/researcher, Sarah Rubidge (2005), has identified different types of artistic research: research which interrogates or tests pre-formulated questions and/or hypotheses which have been derived from artistic practice (what she 
terms practice-based research); research using practice to research practice, often without an initial clearly defined question or hypothesis which, may lead to a formally defined question or hypothesis (practice-led research); and research in which artistic practice is a primary, not second, research methodology, that is, practice as research. Of these, only the first can be undertaken by writers other than the arts practitioner/creator. In a group-authored document, PARIP (Practice as Research in Performance), a project at the University of Bristol established to investigate issues raised by practice as research in performance media (theatre, dance, film, video and television), wrote that in the university environment the practitioner-researcher should fit in with what the university expects from research. This imposes a set of protocols: 1) '...the practitioner-researcher must necessarily have a set of separable, demonstrable, research findings that are abstractable, not simply locked into the experience of performing it; and 2) it has to be such an abstract, which is supplied with the piece of practice, which would set out the originality of [the] piece, set it in an appropriate context, and make it useful to the wider research community’ (Piccini undated, p. 12). These protocols, as Brian noted, focus on contributing to the body of knowledge. Drawing on the OECD (Organisation for Co-operation and Development) definition of research, composers Thomas Reiner and Robin Fox (2003), both working in academia, discussed three principal criteria for music composition to qualify as research. It would have to be: i) 'of an investigative nature, ii) the investigation would have to be systematic, and iii) the investigation would have to result in an original contribution to knowledge' (p. 5). They see no problem with composition as investigative and argue that both 'experimental music making [and]...research-based composition' (p. 6) occur through a systematic approach. In order to ascertain original contribution to knowledge, Reiner and Fox say that 
examiners in music composition have to have sufficient awareness of the repertoire in order to be able to assess the level of originality in works submitted for tertiary examination. They find that terminology referring to a submitted portfolio of compositions as 'creative work' (p. 3) is somewhat degrading, and argue against creative work as a research equivalent instead of 'a form of proper research in its own right' (p. 7) where information such as 'form, rhythm, sound color, movement, repetition, variation, contrast...constitutes aesthetic knowledge, that is, a form of knowledge that is related to the perception, cognition, and appreciation of beauty in its broadest sense' (p. 7). In secondary school curriculum documents, drama is described as a way of knowing; but Ava finds this is not fleshed out, and the same gap exists in the tertiary sector. She feels that academia considers arts practice '.. as a kind of knowledge that generates feelings rather than knowledge in the broader sense of the word'. If approaches to research funding are any indication, it would appear that contemporary academia has difficulties working with these sorts of criteria.

\section{The insider - practice-led research}

Four participants spoke of the need to empower the artist to write about their own artistic work rather than have an outsider do this, what Rubidge calls practice-led research. The fact that those who write about arts practitioners get more 'points' than those who undertake the arts practice was felt to be unfair and made some practitioners feel their work, as practice, wasn’t legitimate in the university environment, although this has since changed in Australia. Ava spoke of the power relationship established when someone else writes of another's arts practice: 'I find it so infuriating when I am on the receiving end of it...I feel very uncomfortable when I am one of the perpetrators of it'. Theatre practitioner, Richard Schechner (1988) 
sought to identify performance in both cultural and experiential terms. In doing so he differentiated insiders from outsiders. While his work called up drama and performance practices across cultures, the experience of being inside the performance is crucial to his discussion, as it was to Antonin Artaud and Bertolt Brecht, the artistresearchers who preceded him and set the model for this sort of inquiry. Schechner and theatre practitioner Victor Turner (1982) have been crucial in the attempt to systematize the performance experience. Turner's anthropological readings of performance - his work on liminality in particular - enabled Schechner to construct models of teaching and learning that contributed to the development of contemporary performance practices. For Paul Carter (2004), being within (rather than abstracted from) the performance is central to the experience because 'creative knowledge cannot be abstracted from the loom that produced it' (p. 1). It is here that the artistacademic can offer insight of a kind not available to the non-practitioner. And there is some equivalence with recent research into indigenous cultural understandings. Linda Tuhiwai Smith (1999), for example, argues for a reclaiming of research into indigenous cultures by indigenous peoples: those within the culture, its language and imagination. The insider, whether practitioner or knowledgeable listener/observer, is required to have a deep knowledge of the arts practice in order to understand and appreciate arts practice as a site of knowledge (Blom, Wright and Bennett, 2008), rather than listening or viewing for enjoyment's sake alone, a point Reiner and Fox (2003) identified earlier in this paper as crucial to the examination of music composition when assessing originality in works.

\section{Practice-based research}


Yet researchers writing what Rubidge calls practice-based research can contribute key issues in the discussion of arts practice as a site of knowledge. And Charles Wilson (2004) warns that artists' self-representations through interviews and writings (and he is talking about composer György Ligeti) can become a type of rhetoric, promoting an image of 'the heroically independent creator' (p. 8) which is not necessarily true. In her study of an 'an eminent composer' plus current and past composition students of that composer-teacher, Barrett (2006) drew on models of 'eminence' studies of creative practice by Gardner, Csikzentmihalyi and John-Steiner to discuss twelve distinct observable strategies which emerged through analysing video footage of six one-hour composition tutorials. These strategies included, among others, extended thinking, referencing work to and beyond the tradition, setting parameters for identity as a composer and provoking description and explanation from the student, which revealed 'complementary themes' (p. 43) in relation to the composer's teaching approach: 1) composer model (language and life-style); 2) enterprise; and 3) composer 'voice'. In her concluding remarks, Barrett noted that while the composer appeared to gain little professionally from the teaching and learning relationship, teaching composition assisted him in the 'reassessment of his “core values”' (p. 43). There are research projects of equivalence across the human sciences. Sociologist Laurel Richardson (1997) argues that experiments with textual voice, frame and theater can be crucial to a researcher seeking to understand and communicate subject matter. She believes it has a significant place in overcoming troubles 'with the ethical issues of doing research on others' (p. 3). Similarly, Norman Denzin (2003) identifies a 'performance turn in the human disciplines' (p. ix), hence a need to use understanding of the performance process to develop and articulate the ethnographic imagination. 


\section{Conclusions and discussion}

Arts practice as a site of knowledge/research

All academic participants considered their arts practice to be a site of knowledge, but the artistic outcome itself was not regarded by all as research. Several factors effected whether participants felt the process or outcome is a site of knowledge/research. Firstly, the type of medium in which the arts practice was situated seemed to play a role. Working within the new medium of electroacoustic music, Brian recounted how curious audience members might comment after a performance, ““I couldn’t work out why that sound came out in the dance and did x?”', to which he would respond, “"well you shouldn't have to. It's not really relevant.”, Despite audience interest in the electroacoustic performance outcome, Brian felt that the process itself should be shared with others in written form in order for the activity to be considered research. Henry, working within the established medium of classical music as an organist and harpsichordist, has an audience which is likely to know about aspects of the preparation process - that is, have insider knowledge - which can be used to discern and evaluate the outcome, that is, the keyboard recital. For Henry, therefore, it was the lack of university recognition for the product which led him to document the process. Secondly, arts practices have different time dimensions. The ceramic product is a static art work and therefore the knowledge is in the process; whereas dance, theatre and music take place in real-time. They are often ephemeral, with a continual and increasing awareness of the outcome also being research and/or a site of knowledge. Thirdly, participants spoke of the different physical aspects of their arts disciplines. It was difficult for dancers and actors to keep their bodies ready for the large physical motor skills required for their arts practice in addition to the time required for practice and for analytical writing. These practitioners often chose to 
focus on one activity. Music performers also struggled with the practice and time balance, and with maintaining a high level of technical skill; however, composers seemed more able to juggle arts practice, time and analytical writing. Fourthly, the public arena for the medium seems to impact on interest in analyzing the process. Damon chose not to analyze and write about his song writing process for reasons shared by many commercial successful songwriters - because of the perceived mystery of the process. For Ava, writing about the acting process served to inform administrators and policy makers and their thinking about sustainable arts practice and the nature of cultural development over time in Australia. However both Damon and Ava were new to academic writing and post-graduate study and appeared to be less immersed in, and therefore less convinced by, writing and thinking about their artistic practice.

\section{How arts practice is research}

Participants reflected the literature in the variety of different ways they held artistic practice to be research, especially in relation to the process (see Table 4). Arts practice is, for example, intuitive, serendipitous and unfolding. It involves arduous skilled regimes and knowledge of structure, timbre and other technical elements. It is holistic with the human being as part of this site of knowledge - visceral, spiritual and sensory perception, involving emotions, social intelligence, artificial intelligence, life history, interaction and collaboration with others. It is about itself, involving tacit knowledge and aesthetic knowledge (largely non-verbal). It is also beyond itself, involving storytelling and positioning the artist as a public intellectual who is part of an international community of arts practice. 
Table 4: How respondents describe artistic practice as research

\begin{tabular}{|c|c|c|c|}
\hline $\begin{array}{l}\text { Aspect of artistic } \\
\text { practice }\end{array}$ & $\begin{array}{l}\text { Research/not } \\
\text { research }\end{array}$ & $\begin{array}{l}\text { Respondent } \\
\text { descriptors }\end{array}$ & Respondent sub-descriptors \\
\hline \multirow{2}{*}{$\begin{array}{l}\text { Performance } \\
\text { outcome }\end{array}$} & Research & Broad notions & \\
\hline & Not research & Site of knowledge & \\
\hline \multirow{14}{*}{$\begin{array}{l}\text { Performance } \\
\text { process }\end{array}$} & \multirow[t]{14}{*}{ Research } & Intuitive & serendipitous, unfolding, unexpected \\
\hline & & \multirow[t]{2}{*}{ About itself } & Arduous skilled regimes \\
\hline & & & $\begin{array}{l}\text { Structure, timbre \& other technical } \\
\text { elements }\end{array}$ \\
\hline & & \multirow[t]{8}{*}{ Holistic } & Human being, whole self \\
\hline & & & Visceral \\
\hline & & & Emotions \\
\hline & & & Sensory perception \\
\hline & & & Spiritual \\
\hline & & & Social intelligence \\
\hline & & & Artificial intelligence \\
\hline & & & Life history, cultural DNA \\
\hline & & \multirow[t]{3}{*}{$\begin{array}{l}\text { Communicating } \\
\text { beyond its medium }\end{array}$} & $\begin{array}{l}\text { Storytelling, public intellectual, part of a } \\
\text { broader tradition, drawing on science, } \\
\text { psychology, philosophy etc. }\end{array}$ \\
\hline & & & Collaboration with others, interactive \\
\hline & & & $\begin{array}{l}\text { International community of arts } \\
\text { practitioners }\end{array}$ \\
\hline
\end{tabular}

The findings suggest a frame within which to advocate the equivalence of artistic research with traditional scholarly research. They also suggest a rationale for arguing against this, focusing instead (or perhaps as well) on a wider understanding of what constitutes knowledge. Composers Reiner and Fox, both working in academia, discuss music composition at post-graduate level as a site of knowledge drawing on the OECD (Organisation for Co-operation and Development) definition of research. According to this definition, for composition to qualify as research: i) it would have to be 'of an investigative nature; ii) the investigation would have to be systematic; and iii) the investigation would have to result in an original contribution to knowledge' (Reiner and Fox, 2003, p. 5). Investigation and systematic investigation is present through arduous skilled regimes, structure, timbre and other technical elements, and 
communicating beyond its medium by engaging with other disciplines. An original contribution to knowledge can be judged by those with experience in the discipline one's peers. However, artistic research is more than that and there is a compelling argument that rather than being merely an equivalent, it should be recognized as research in its own right. Through a recognized and acknowledged understanding of knowledge through and about the whole self, emotions, senses, different intelligences, life history, and collaboration both artistically and through discussion with others internationally, a wider view of research is experienced. These seemingly ineffable sources can almost always be 'translated' (Biggs 2004 p. 9) through words and other media and therefore communicated to others such as students, directors, other arts practitioners and different audiences - whether through the spoken or written word.

The impact of reflective, analytical thinking about one's arts practice

As discussed above, some notions of arts practice as research marry with the definition and reality of traditional research but others are different and have the potential to take ideas of research into new directions. Because of these similarities and differences, the impact of thinking analytically and reflectively about one's artistic practice has several outcomes, including the contribution made to the practice itself. This in turn impacts on, and feeds into, teaching within this practice.

Writing about practice requires time as well as a different mindset from that employed in practice, and this can force a division between practitioners and scholars. Different ways of knowing that emerge from within an arts practice can result in the adaptation of traditional research paradigms or in new research paradigms developed for writing 
about one's arts practice. Knowledge can take the form of aesthetic knowledge that is largely non-verbal, and it can require 'insider' knowledge and/or experience. The process of engaging in, reflecting and analysing, writing, and feeding back into one's own arts practice and teaching, is, itself, an 'artistic action research' model that contributes to the discipline area as well as the development of the individual artistacademic.

\section{Future research areas}

The findings identified several key areas for future study. Firstly, the inclusion, by the ERA, of artistic practice as research opens up several areas of future investigation including the evaluation, ranking and assessment of such research. This will, no doubt, be a contentious issue, and mirrors similar assessment of artistic practice in other parts of the world. Secondly, as part of a mindful practice, arts practitioners in academia should be encouraged and supported to engage in the many forms of artistic research, thereby developing a positive perception of practice as research. These are skills increasingly valued for undergraduates, post-graduates and academics engaged in arts practice. When combined with an understanding of how artists in academic move fluidly between different roles, this calls for recognition, by universities with visual and performing arts courses, of the multi-faceted identity of the artist in academia and the need to educate students about this likely identity.

Thirdly, the influence of the university's requirements plus the different roles of artist and academic impact on an artist-academic’s thinking and creating a constant cycle and transfer of knowledge. This raises, in turn, questions about changes to the artist academic's learning, their understanding of the arts and the arts community, and of 
social priorities and social relationships as a result of their arts practice being situated in a university. And, finally, whether fair or unfair, the emphasis on the written word as research encourages art practitioners to write about their work (and that of others), which feeds their own practice and, in turn, their teaching. While academia has encouraged an environment for thinking and writing about arts practice, it also needs to understand that the artistic research process is quite the reverse of the traditional research paradigm - analyse to create becomes create then analyse. This raises the issue of who reads 'practice-led' writing and what is gained from this reading.

In many cultures, artists and their arts practice are recognised and valued without the need for written publications. The findings of the study have implications for academics, for students, and for universities in recognising the research inherent within arts practice itself. Critically, they highlight the import and value of practiceled writing in understanding and communicating new knowledge, new methods, and new definitions of research.

\section{References}

Angilette, E. (1992). Philosopher at the keyboard. Metuchen, NJ: Scarecrow Press.

Barrett, M. (2006). Creative collaboration: an 'eminence' study of teaching and learning in music composition. Psychology of Music 34: 195-218.

Blom, D., Wright, D., \& Bennett, D. (2008). The artist as academic: arts practice as a site of knowledge. In Michael Hannan (Ed.), Educating musicians for a lifetime of learning, proceedings of the $17^{\text {th }}$ International Seminar of the Commission for the Education of the Professional Musician (CEPROM), 
International Society for Music Education (ISME) (pp.5-9). Western Australia: ISME.

Burnard, P., Dillon, S., Rusinek, G., \& Sæther, E. (2008). Inclusive pedagogies in music education: a comparative study of music teachers' perspectives from four countries. International Journal of Music Education - Research 26(2), 109-126.

Carter, P. (2004). Material thinking - the theory and practice of creative research. Melbourne: Melbourne University Press.

Charmaz, K. (2000). Grounded theory - objectivist and constructivist methods. In N. Denzin \& Y. Lincoln (Eds.), Handbook of qualitative research (2nd edition, pp. 509-535). Thousand Oaks: Sage.

Crossman, B. (2005). Asian-Australian interactions: Personal compositional voice and after-resonance renewal, CAESS Conference Proceedings. University of Western Sydney, October, 2005.

Denzin, N. (2003). Performance Ethnography: Critical Pedagogy and the Politics of Culture. Thousand Oaks, CA: Sage Publishing, Inc.

Dixson, A.D., Chapman, T.K. and Hill D.A. (2005) Research as an aesthetic process: extending the portraiture methodology. Qualitative Inquiry. 11, 16, 16-26.

Flanagan, B. (1986/87). Written in my Soul - Conversations with Rock’s Great Songwriters. Chicago: Contemporary Books, Inc.

Flick, E. (2002). An Introduction to Qualitative Research. Sage Publications: London.

Frascati Manual (2002) Proposed standard practice for surveys on research and 
experimental development. OECD (Organisation for Economic Co-operation and Development) Paris Cedex: France. Retrieved March $8^{\text {th }}, 2010$ from http://www.oecd.org/document/6/0,3343,en_2649_34451_33828550_1_1_1_1 ,00.html

Odam, G. (2001). Research in the arts: Issues in the development of new and relevant techniques of arts research in music, the arts and arts education, Music Education Research Vol.3(1): 77-86.

Organisation for Economic Co-operation and Development (OECD). Building knowledge. Retrieved October 282007 from http://www.oecd.org/about/0,3347,en_2649_39263301_1_1_1_1_37455,00.ht $\mathrm{ml}$

Patton, M. (1990). Qualitative evaluation and research methods (2nd ed.). Thousand Oaks, CA: Sage Publishing, Inc.

Piccini, A. Undated. An historiographic perspective on practice as research. Retrieved 15 August 2006 from PARIP: <http://www.bris.ac.uk/parip/artexts.htm>.

Reiner, T. and Fox, R. (2003). The research status of music composition in Australia, Australian Journal of Music Education, No. 1: 3-9.

Richardson, L. (1997). Fields of play. New Brunswick, New Jersey: Rutgers U.P.

Rubidge, S. (2005). Artists in the academy: Reflections on artistic practice as research. Paper presented at Dance Rebooted: Initialising the Grid, Deakin University, December. Retrieved Oct 17, 2007, from http://www.ausdance.org.au/resources/publications/rebooted/rebootedpdfs/Ru bidge.pdf

Schechner, R. (1988). Performance theory._London: Routledge. 
Smith, L. (1999). Decolonising methodologies London, Zed Books

Turner, V. (1982). From ritual to theatre. New York: Performing Arts Journal Publications.

Wilson, C. (2004). 'György Ligeti and the rhetoric of autonomy’, Twentieth -century music 1/1: 5-28.

Wright, D. (2002). Reflections on writing a cross-cultural theatre text, Double Dialogues, Issue 2: Winter 2002. Retrieved Oct 21, 2008 from http://www.doubledialogues.com/archive/issue_two/wright.htm 